\title{
Effects of Devolution on the Restructuring of the Provincial Administration in Kenya: A Case of Nairobi City County
}

\author{
Cynthia M. Mutinda ${ }^{1}$, Dr. Patrick Mbataru ${ }^{2}$ \\ ${ }^{1}$ Master of Public Policy and Administration of Kenyatta University, Kenya \\ ${ }^{2}$ Department of Public Policy and Administration, Kenyatta University, Kenya
}

ABSTRACT

ABSTRACT

Devolution in Kenya is about decentralising political, financial and administrative powers to forty seven counties. Kenya had practised devolution through the one year Majimbo government which lasted in 1964, before the highly centralised provincial administration was established. The provincial administration was centralised and gained control over all decentralized ministerial functions in the country; as an extension of the executive office of the president in the field. The Constitution stipulates that the provincial administration be restructured to align with the devolved administrative structure. Little research has been done on the structural frictions that arise from the fact that central governments are keen to retain or recapture the same authority that have been devolved to the lower level governments. Therefore, on this basis this study sought to establish the effects of implementing devolution on the operations of the Provincial Administration. The study was anchored on the objectives of establishing how devolution had shaped the structure of the Provincial Administration in Kenya; examine the extent to which functions of both County and National Government Administrators are interlinked and to identify the challenges faced in the implementation of Schedule Four of the Constitution. Both primary and secondary data were used. The study was guided by the Structural Functionalism theory of Emile Durkheim, which compare the society to an organism comprising of structures that influence each other for its own existence. A case study design was used with Nairobi City County as the study area. A simple random sampling technique was used to select the sample size for the questionnaires from the sample frame. Further the study used purposive sampling technique to select key informants for the interview guide. SSP version 21 and Content analysis were used to analyse the descriptive data. Data was presented in tables, charts and prose form. The study found out that the provincial administration had restructured through change of tittles and administrative units but not functions, there were points of roles interlinkages some of which are not procedurally and devolution was facing challenges such as: - revenue allocation, administrative and bureaucratic culture, organisational capacity and stakeholder mistrusts. The study concluded that duplication of functions by both levels of government still exists and that the aligning of the provincial administration with the schedule four was yet to be fully attained. Devolution advance national unity by recognising diversity and that it promotes participatory and transparent exercise of authority. The study recommends the enactment of legislation on functions to regulate the constitutional functions of the two levels of government and that commission on Revenue allocation to focus on Wards as the point of reverence in budgeting as they happen to be the service delivery vocal point. It further recommends the need for concerted efforts in creation of awareness on matters devolution through a structured civic education program. The fourth schedule needs to be implemented in tandem with the county government act 2012, for separation of functions between the National and County governments. There is need further research on devolution in future and to widen the study by including a bigger samples size, widening its scope and other variables not covered by this study. 
International Journal of Current Aspects, Volume 4, Issue 2, 2020, PP 50-68, ISSN 2616-6976

[IJCAB

Key Words: Devolution, Devolved Government Structures, Restructuring of the Provincial Administration in Kenya

DOI 10.35942/ijcab.v4i2.127

\section{Cite this Article:}

Mutinda, C., \& Mbataru, P. (2020). Effects of Devolution on the Restructuring of the Provincial Administration in Kenya: A Case of Nairobi City County. International Journal of Current Aspects, 4(2), 50-68. https://doi.org/10.35942/ijcab.v4i2.127

\section{Introduction}

Devolution has been practiced worldwide by different countries with each choosing the practice which suits the purpose for devolved government. For the purpose of this study, I looked at how the first five years of devolution in Kenya had imparted the restructuring of the highly centralized Provincial Administration in the office of the President (Constitution of Kenya 2010, Article 262). Barnett Hilaire, (2009) argues that the European member states have shown preference to transfers power to sub national governments. Belgium and Italy have favoured federalism hence joining the earlier federates of German and Austria whereas Portugal and the United Kingdoms(UK) have transferred considerable power to most of their region but remained Unitary states (Barnett Hilaire, 2009). In Britain devolution is practised through the autonomy of the Wales, the Northern Ireland Scotland and the Mayor of London. This transfer of power was as a result of the Scottish referendum of 1997 and that of the Wales in 1998 both of which were motivated by the need to be legitimate states and have the autonomy toward service delivery and development (Barnett Hilaire, 2009). Additionally, the devolution in United Kingdom received an empowerment by the commitment of the 1997 labour party manifesto and from Good Friday Agreement of April 1998 (Akash Paun et al. 2019).

Conversely, to the case of Kenya's devolved system where all devolved units have similar powers and authority; these devolved regions of the United Kingdom do not enjoy similar level of authority. For instance, Scotland has independent judicial system unlike the others. The Scotland Act 1998 section 51 makes statutory provision for administrative support to be provident to the Scottish executive by the home civil service but silent on their devolved specific functions in Scotland (Barnett Hilaire, 2009). Akash et al. 2019, notes that Northern Ireland devolution system worked well to minimise violence through a functional Assembly and executive, coupled with good working relationships amongst the top ranking communities. Nevertheless, devolution failed owing to institutional collapse. Northern Ireland has thereby had no elected devolved government since 2017. They add that there is notable public lethargy towards the parties' inability to offer good governance though Ireland remains a devolved entity. Admittedly, the expectation by the populace to that the parties would be open, responsive and accessible was unrealistic and not achievable. Parties worked in power-sharing formulae for none of them won majority seats in the assembly (Akash et al. 2019).

In the United States of America devolution has been anchored on responsibility. Tannenwald (2012) notes that, political goodwill has been wanting with the federal government holding dominantly on power. Nevertheless, the functions of the state have been declining in respect to those of the federal government over the last two decades. The devolution debates have been majorly centred on medical program and both primary and secondary education welfare (Tannenwald, 2012). Devolution in china resulted from a decision of the central government to 
achieve innovation reforms. Sub national government agency were appointed and subordinated to the national government for accountability purposes (Barhdan and Mookherjee, 2020). This resulted to transferring much of the economic power as compared to the political power. Contemporary devolution in china is centred on provinces autonomy and budgetary control. China practise devolution through several levels as in provinces, counties and townships.

India is devolved through states. The federal central government has largely promoted the devolution agenda for its own benefits (Besley and Burgess, 2002). Its legislation and administration dominance has ensured that devolution is influenced and managed for the central governments advantage other than the devolved units. For instance the five year development plan and colonial British rule of central government coordinating the export and political control has preserved the centres legitimacy over that of the devolved units (Besley and Burgess, 2002). India was majorly an industrial country focusing more on industrialization and economic growth with less emphasis on poverty reduction. The constitutional amendments of 1993 saw agricultural cooperation and local government as key drivers to poverty eradication. Previous decentralization attempts had not been as effective as this particular one which granted legal identity to Districts, Economic blocks and villages as units of devolution (World Bank 2000a.7). However, financial and fiscal powers have been held by the central government through parallel bodies.

Besley and Burgess (2002) argue that India has devolved administratively but its central mechanism of planned economy undermines the political and fiscal power of the regions. The central government is said to dictate financial and economic goals of the states. They further note that this dominance resulted to fiscal imbalances which seriously affected the national budget in the 1980's and brought about the call for fiscal devolution to counter debts through prioritizing expenditure and planning at regional level. According to Omolo A. (2010), devolution has gradually taken root in the last three decades in Africa. The three leading federal state of Africa which are; Nigeria, South Africa and Ethiopia have devolved system of government. Similarly, the unitary states in Africa have also shown keen interest and success in devolution. For example, Tanzania, Ghana, Uganda, Rwanda and Kenya have devolved systems of governance. He further argues that each country has a unique explanation towards devolution. For instance in South Africa, the state demanded implementation of devolution as a means and strategy to rebuild the country after the long period of apartheid rule. There was a feeling that governance through provinces and local counties would be better for social integration, democratic enhancement, and community and environmental development.

Uganda's devolution in contrast to South Africa's was engineered from the top through consultative forums and pilot programme to restore the country's political stability (Kauzya, 2007). It was a government political reform to ensure accountable and transparent political institutions. Rwanda's devolution was a government driven agenda to eradicate poverty and ensure socio-political coexistence after the 1994 genocide (Kauzya, 2007). In both Uganda and Rwanda there is a form of national government administration cascaded to the lower levels to coordinate central government administration functions and act as linkages to the central government. Kenya's devolution is a key feature in her 2010 constitution. It resulted as accumulation of many reasons which the Kenyan people felt could only be best dealt through a devolved system of government. The devolution structure is two tires where power and resources have to be dispersed from the central national government to forty seven counties. The constitution of Kenya 2010, article 174 outlines the why to the power and resources sharing. "These include: facilitating equitable development and sharing of resource (including access to essential services), 
enhance public participation and involvement in governance as well democratic accountability in the exercise of power, national unity through recognising diversity and protection of marginalised communities, among other objectives. Through their respective institutions, county governments same as the national government are expected to pursue these objectives (Constitution of Kenya 2010). Kenya constitutional review process is a main point of reference for the country's quest for devolution. The constitutional process has had need for devolution as one of its main agendas culminating to the chapter eleven of the 2010 constitution. Colonial rule in Kenya anchored on socio-economic discrimination and segregation between the masters and the natives bore development marginalisation and inequalities. This has seen concerted calls for equity through successive post-independence governments. However all these calls fell on deaf ears as the Commission of Inquiry to the 2007/2008 Post-Election Violence documents (Waki Report, October 2008). This commission went further and argued that the main causes of the violence could only be better addressed by devolved system of governance. These main causes included but not limited to the following: high levels of poor urban based idle youths wallowing in unemployment and poverty who could easily be mobilised and militarized towards violence, evident central government abuse of state power and resources and impunity amongst the political elites.

The commission argued that devolution would dismantle the over centralisation of state power, resources and control. This would similarly foster national unity by bringing together different groups to the control of governance. Devolution was envisaged to avail the needed capacity for equal development and effective public service delivery in the country. This would subsequently address the equitable development gap and offer equal access to service delivery. Furthermore, entrenching and implementation of the Devolved system of governance in the Kenyan constitution was foreseen as a way of minimising or curbing altogether future political conflicts. Devolution was practiced in Kenya at independence until 1964 when Kenya reverted to a unitary state through a constitutional amendment (Burugu, 2010). This enabled decentralization to be carried out through the provincial administration and the Kenya local authorities. A form of devolution termed "Focus for Rural Development" was implemented in 1984 without sustainable success (Chitere and Ireri, 2004). The local authorities were managed through the Local Government Act cap 265 Laws of Kenya. However, they had minimal autonomy as in terms of legislation and finance while the central government would manage the local authorities administratively. Nairobi City Council was one of the local authorities (Nairobi City Council) which has been currently devolved in to the Nairobi City County.

Provincial administration on its part was an extension of the executive office of the president which had overwhelming control over all the decentralised ministerial functions and over shadowed the parliament and the judiciary arms of the government (Ghai, 2011). The provincial administration performed such executive roles as quasi judiciary, coordination of security and development, and adjudication among others. It was this over centralization through the provincial administration that created the need for devolution as it was viewed as an abetment of all bad governance trough imperial presidency corruption, nepotism, electoral malpractices, social and regional marginalization and insecurity among others. The provincial Administration, currently known as the National Government Administration according to National Government Coordination Act, 2013, was instituted during the Kenya colonial administration period to permeate the executive authority to lowest level. After independence and collapse of devolution (regional governments), the national government used Provincial Administration as a pillar from which all government function were anchored and ingrained. Provincial Administration had been cascaded in to eight 
provinces. These provinces were each subdivided into a number of districts depending on population and land size although at times political allegiance was considered. The districts were cascaded to divisions which were subdivided in to locations. Under the locations were the sublocations which acted as the lowest level of the structure.

Ghai, (2011) argues that the Provincial Administration had attracted a lot of dislike from many Kenyans because of its roles and position of authority, and influence over local politics. Ghai further notes that for two decades Kenyans debated and struggled to make a new constitution and the hatred for provincial administration was evident as many opinions where for its crapping and total abolishing in the 2005 referendum. It could be on this basis that the Provincial Administration was never mentioned in the chapter on devolution or schedule four of the Kenya Constitution 2010, but on the consequential provision of schedule six to ensure that it remained a non-official constitutional agency just as it was in the previous regimes. Article 189 of the Kenya Constitution (2010), articulates that the two levels of government shall carry out their roles with respect for functional integrity of each other. This article ensures that the central government does not neutralise the counties power as it happened with regions in 1964. Kenya's devolution has been viewed by many as a great strategy to move from centrality of Provincial Administration to desired lower levels of power however, if not properly managed through constitutional implementations the devolution prospects could be still born (Mungai, 2013). This is the background upon which this study sought to find out how the implementation of devolution in Kenya had influenced the restructuring of the Provincial Administration in terms of structural, composition and role differentiation.

\section{Statement of the Problem}

Devolution in Kenya based on both political and socio-economic contexts. It was occasioned by the need to achieve equity of socio-economic development and access to public services through decentralization of power and resources to the forty seven counties. These powers and resources were being managed and distributed through a centralised administrative structure of provincial administration. The structure as it were, fostered an impediment to the success of devolution. The 2010 Constitution chose to address this challenge by asserting the need for the restructuring of the Provincial Administration to be aligned with the devolved system structure. The constitution devolved political, administrative and fiscal powers to forty seven Counties from the national government where the provincial administration previously took charge. This Constitution (2010) was promulgated on the $27^{\text {th }}$ of August, 2010. It envisaged that the Provincial Administration be restructured to align to its chapter Eleven on devolution and fit within the devolved government structure. The restructuring was to commence on the date of promulgation for a period of five years ending in August 2015. Devolved structure was to take shape as per the Constitution's ratification after the March 2013 elections results announcement.

The transitional authority was created to foresee the devolution process ensuring smooth transition of formerly National government functions, employees and assets to County governments. The parliament created and passed the National Government Coordination Act 2013, which came to force after the announcement of the presidential results of March 2013 general elections. The National Government Coordination Act 2013, laws of Kenya has laid down the structure of the devolved Provincial Administration but left out its specific roles in the devolved system of government. At the same time, the County Government Act 2012, has put in place devolved administration to supervise, coordinate and manage devolved functions most of which had been performed by the Provincial Administration in the former regime. Studies have documented that 
Kenya at independence had a devolved form of government which only lasted for one year before the centralised provincial administration was established. This history would negate the envisioned benefits of devolution if repeated (Ghai, 2011). Bagaka (2010) argues that, phased devolution guarantee much success, like the cases of India and Uganda as compared to a one time all functions devolution in the Kenyan case ; which he refers to as a "big bang" which could result to a "still birth". The Kenya Devolution Transitional Authority was folded in March, 2016 after working for four years. This authority was mandated with ensuring a coordinated transfer of functions devolved from the National government to the counties (Henry Owino, 2016). According to the Authority's working papers, there was remarkable success on the mandate besides challenges which hindered full goal attainment. Admittedly, there was evident reluctance on the part of National government to cooperate with the Authority. This coupled with lack of term extension by the National assembly and financial challenges meant much work was left incomplete. This pose the fear of recentralisation of the devolved functions as Owino (2016) observes. The Authority however attempted to foresee that all the fourteen functions as per the Schedule four of the 2010 Constitution we transferred. This wholesome transfer made Kenya's devolution unique in that all functions were moved once to new structures. The Kenyan form of devolution hence would be a one of its kind therefore the need for a study on its operationalization; the reason for undertaking this study.

Nonetheless, the Provincial Administration is far from releasing grip from government powers and resources and the structure is yet to be aligned with the devolved system of government. This continuous rigidity in holding unto functions that are supposedly devolved as per schedule four of the 2010 Constitution pose a challenge to the success of devolution. A research carried out by John Solonka in 2015 found out that full alignment of the previous administrative structures to the devolved system of government would ease implementation of devolution in Kenya. However, he did not explore on the effects of implementations of devolution on the restructuring of the Provincial Administration which this research intents to carry out and explore further on the subject. To attain this, the researcher employed a qualitative case study approach, with Nairobi City County being used to gather both primary and secondary data and information. Specifically the researcher employed SSP version 21 and content analysis to analyse the descriptive data and put forward appropriate policy recommendations towards intervention.

\section{Objective of the Study}

The main objective of the study was to establish the effect of devolution in the restructuring of the Provincial Administration. The study was guided by the following research objectives.

i. To establish how devolution has affected the structure of the Provincial Administration in Kenya.

ii. To determine the interlinkages of both county and National government functions.

iii. To identify the challenges faced in the operationalization of Schedule Four of the constitution.

\section{Theoretical Review}

This study was guided by the structural functionalism theory which holds that society is compared to an organism comprising of structures referred to as social institutions. The social institutions carry out different functions in the society for its very own existence. The social institutions are interrelated and interdependent such that one can affect or influence the other or the whole and/or 
vice versa. The social institutions efforts are geared toward the well-being and stability of the society. In relation to this theory, the introduction of devolution in Kenya means that a need (over centralization) was felt prompting societal dysinfuction which required reorganisation of the government structure. This dysinfuction called for social change culminating to constitutional change hence, different government structures have been affected and need to respond positively for social order to be achieved. In response, the Kenya constitution (2010) has redefined the structure of government in to two tires (national and county governments) and the three arms of government to include the independent commissions. Roles previously carried out by different arms have been redistributed to these other arms (commissions) and other roles devolved to the counties.

Unlike the conflict theory, which focus on the negative aspect of society revolving around conflicted and ever changing nature of society which force social order on to society through competition and domination by those powerful people in the society, functionalism theory defend status quo in society by believing that people cooperate to effect social order in the society by depending on each other through shared public values for society to remain relatively stable (Tony Bilton, 2002). The Kenyan devolution is anchored on interdependence and cooperation between the two tires of government which are interlinked by shared values. Owing to this therefore this study used the structural functionalism theory to find out how implementations of devolution, has affected the restructuring of the Provincial Administrations to achieve the expected functional devolved system of government in Kenya.

\section{Conceptual Framework}

Independent variables

Devolution
Dependent Variables

Restructuring of the Provincial Administration

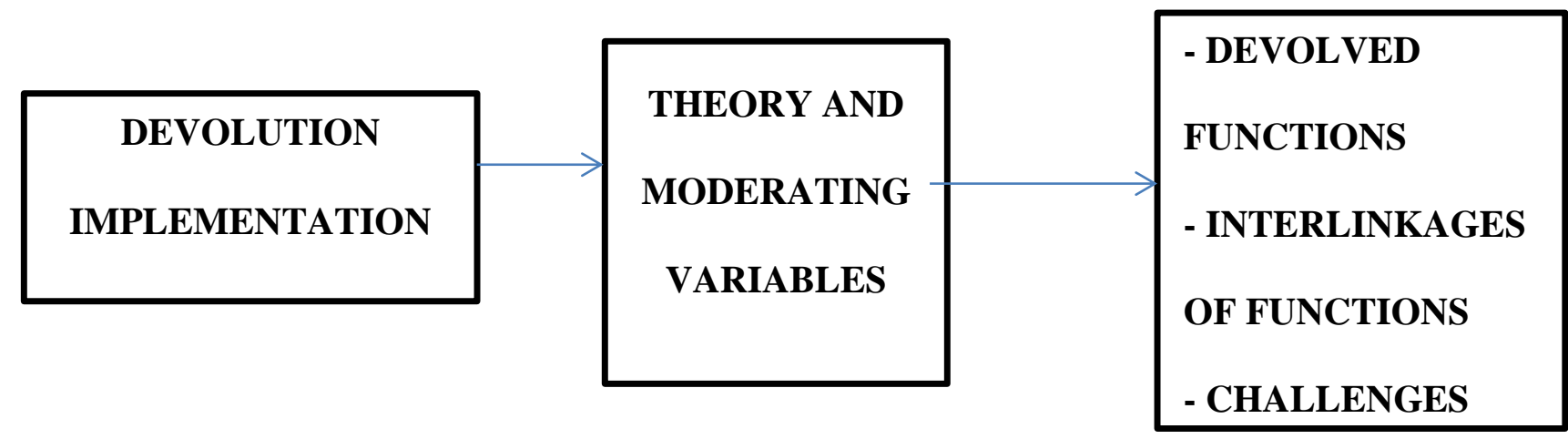

\section{Research Methodology}

The design for this study was descriptive case study. A descriptive study focuses on finding out the what, where and how of a phenomenon (Cooper and Schindler, 2003). Tony Bilton (2002), notes that a descriptive case study have to do with the deep exploration of problem solving circumstances in which problems are pertinent to the research problem, and that it provides a reliable and representative information on the area of study. Owing to these factors thereby, this study sought to establish the effects of devolution in Kenya in the restructuring of the Provincial Administration, was guide by the descriptive survey research design. 
The research variables were devolution being the independent variable and structure of the Provincial Administration as the depended variable. Implementation of devolution would affect the restructuring of the Provincial Administration in different ways since the constitution advocated for the later to be restructured in accordance to the former. This study was accomplished in Nairobi City County. The County offered a metropolitan set up, and it's where the targeted population is basically situated and hence it was reached with ease. Nairobi County was among the first counties to implement the County Government Act (2012) by hiring the Ccounty Aadministrators to coordinate devolved functions.

The study area was sampled through simple random sampling technique for the questionnaire. In this case the researcher listed all Sub counties in Nairobi County each on a separate piece of paper. The pieces of papers each bearing the name of Sub counties in Nairobi County was then folded after which the papers were put in a container, The researcher then randomly picked one of the folded paper, eight times from the container. Using this technique the researcher randomly picked eight Sub counties as the study area. The Sub counties that were randomly selected include Kasarani, Embakasi South, Starehe, Mathare, Makadara, Westlands, Dagoreti North and Kibra and systematic sampling was used accordingly to select two sub locations. Further Radom sampling was used to select twenty four participants from each of the sixteen sub locations. Further the study used purposive sampling technique to select key informants for the interview guide; one county commissioner, two assistant County Commissioners, and two field officers as per the County Government structure, two Sub county Administrators, three Ward Administrator and two civic leaders.

The required sample size was calculated based on Fishers et al. (1998) recommendation as follows: The sampling plan describes the sampling unit, sampling frame, sampling procedures and the sample size for the study. The sampling frame describes the list of all population units from which the sample was selected. The study employed every element in the target population so as to give a chance to every respondent. This technique ensured that bias was not introduced regarding who were included in the census (Kothari, 2005). The researcher used simple random sampling procedure to get a sample totalling to 384 respondents comprising of 384 local residents. Prior to processing the achieved responses, the finalized questionnaires were revised for completeness and dependability. Quantitative data gathered was analysed using SPSS software while qualitative data gathered collected using interview guide was analysed used using thematic means. Pragmatic content analysis was used to understand why the respondents perceive and belief what they said in determining devolution as a cause to restructuring of the Provincial Administration. The words, phrases and signs were classified to in terms of their probable causes and effects.

\section{Study Findings}

\subsection{Effect of Devolution on the structure of the Provincial Administration}

This study on its first objective, sought to examine the extent to which respondents concurred with the following statements that sought to establish how devolution had shaped the structure of the Provincial Administration in Kenya. 
International Journal of Current Aspects, Volume 4, Issue 2, 2020, PP 50-68, ISSN 2616-6976

[IJCAB

Table 1: Effect of Devolution on Provincial Administration Structure

Statements

Std.

The reforms had a substantial impact in transforming the institution of provincial administration

Mean Deviation

$4.18 \quad 0.69$

In devolved system the chiefs' office was the most improved in terms of service delivery despite that over $70 \%$ of civil disputes being arbitrated by provincial administration each year

Under devolved structure there is increased coordination and efficiency national government service delivery.

The national government's system of provincial administration will have to be reorganized so that its functions do not overlap with those of the county governments.

There is no framework stating how the security structures at the lower levels should exchange information and collaborate

Provincial administration under devolved system promotes social and economic development and the provision of appropriate, easily accessible services throughout Kenya.

0.69

Under devolved system, provincial administration is merely a change of titles but retention of functions

$4.15 \quad 0.60$

$3.89 \quad 0.64$

$3.84 \quad 0.64$

$3.74 \quad 0.73$

$3.90 \quad 0.59$

$4.16 \quad 0.77$

Under devolved system, the provincial administration provincial commissioners, district commissioners, district officers, chiefs and sub-chiefs have become an extension of the nationa government

Under the devolved structure, the chain of command is simple, less complex and non-confusing

contrasted to the former provincial administration

Provincial administration has been accused of being the face of repression, corruption and dictatorship

Under devolved system, provincial administration foster national unity by recognizing diversity

Under devolved system, provincial administration promotes democratic and accountable exercise of power.

Under devolved system, provincial administration foster national unity by recognising diversity

$\mathrm{Pa}$ under devolved system share state functions within the county as the president may from time to time assign on the basis of mutual consultations.

0.68

$3.87 \quad 0.73$

3.910 .56

$4.01 \quad 0.69$

3.690 .62

Under devolved system, provincial administration recognize the right of communities to manage their own affairs and to further their development

$4.12 \quad 0.66$

From the research findings majority of the respondent's agreed that the reforms had a substantial impact in transforming the institution of provincial administration $(\mathrm{M}=4.18 \mathrm{SD}=0.69)$. This was interpreted to imply that, the National Government Administration had worked its composition and structure to align it with the National Government coordination Act 2012. This is in agreement with Bagaka, (2011) that for devolution to take root, the composition and structure of the National Government Administration had to align with the devolved system of government according to the chapter eleven of the Constitution. These findings also concur with Mwenda (2010), arguments that the devolution system structure and composition would align all government service deliverables to the system where the National Government Administrators would similarly adhere.

The research established that, under devolved system, provincial administration is merely a change of titles but retention of functions $(\mathrm{M}=4.16 \mathrm{SD}=0.77)$. The study established that the Composition had not been greatly varied only the names have been changed. The formerly Provincial commissioners have been differed to pave way for Regional commissioner, the County Commissioner have come in to head the Counties, District Commissioners have been replaced by the Deputy-County Commissioners heading the Sub-counties, while the District officers have been replace with the Assistant-County Commissioner in the wards. However, the Chiefs and the 
Assistant-Chiefs have been retained as they were formerly heading the location and the sublocation respectively.

However, the study found out that the Assistant-County Commissioners are yet to move their operations in to Ward but still holding unto the former structure by operating at divisional level. Thereby, this negates the spirit of devolution held by provision of public goods being bestowed to the lowest level of governance and hence the structural adjustment through devolution not yet achieved as expected. Under devolved system the office of the chief was the most improved in terms of service delivery despite that over $70 \%$ of civil disputes being arbitrated by provincial administration each year $(\mathrm{M}=4.15 \mathrm{SD}=0.60)$. These offices have been noted to have close working relationships majorly for the officers at service point that is; sub-county and wards. This thereby concur with Bagaka (2011) where he argues that Kenya's devolution is limited with national government to retain most of its roles and provide leadership as the intergovernmental agency during the transition period. This he argues is the cooperation and relationships as envisaged in chapter eleven part five articles one hundred and ninety of the Constitutions and thereby the Provincial Administration would also offer leadership and continuity in case a county is suspended by the president. The study established that under devolved system of government, provincial administration acknowledge the ability of communities to take charge of their own affairs and to advance their development $(\mathrm{M}=4.12 \mathrm{SD}=0.66)$.

The constitution in its Fourth Schedule appropriate the county governments the responsibility of ensuring that communities participate in public policy. (The County Governments Act, 2012 Section 3(f) Section 87). The study established that under the devolved structure, the chain of command is simple, less complex and non-confusing contrasted to the former provincial administration $(\mathrm{M}=4.08 \mathrm{SD}=0.67)$. Provincial administration has been previously profiled as a hand of suppression, and corruption $(\mathrm{M}=4.06 \mathrm{SD}=0.68)$ while under devolved system, it's seen to foster national unity by recognising diversity $(\mathrm{M}=4.01 \mathrm{SD}=0.69)$. Under devolved system, provincial administration promotes democratic and accountable exercise of power. $(\mathrm{M}=.3 .91 \mathrm{SD}$ $=0.56$ ) and that provincial administration under devolved system promotes socio-economic development and offer appropriate, simply reachable services throughout the country $(\mathrm{M}=3.90$ $\mathrm{SD}=0.59$ ) these findings concurs with the research findings by Iavorskyi, (2013) contends that ideal organizational structure is a recipe for superior performance.

Further the findings revealed that under devolved structure there is increased coordination and efficiency in the delivery of national government services diversity ( $\mathrm{M}=3.89 \mathrm{SD}=0.64)$, Under devolved system, provincial administration foster national unity by recognizing diversity $(\mathrm{M}=$ $3.87 \mathrm{SD}=0.73$ ), the national government's system of provincial administration will have to be reorganized so that its functions do not overlap with those of the county governments $(\mathrm{M}=3.84$ SD $=0.64$ ), under devolved system, the provincial administration provincial commissioners, district commissioners, district officers, chiefs and sub-chiefs had become an extension of the national government $(\mathrm{M}=3.76 \mathrm{SD}=0.68)$, there is no framework stating how the security structures at the lower levels should exchange information and collaborate $(\mathrm{M}=3.74 \mathrm{SD}=0.73$ ), Provincial Administration under devolved system share state functions within the county as the president may from time to time assign on the basis of mutual consultations. $(\mathrm{M}=3.69 \mathrm{SD}=0.62)$ These findings are in support of the research findings by Kotter (2010); which confirm significant relationship between organizational structure and corporate performance. Further under Article 233 of the Constitution establishes the Public Service Commission to administer the public service at national level. Section 57 of the County Governments Act 2012 establishes County Public 
Service Boards in each county. The functions of the Commission and Boards at the respective levels are to create and manage an efficient system of public service delivery. Further, the commission and the Boards are completely independent of each other except as provided in Article 234(i) where the Public Service Commission can hear and determine appeals in respect of county governments' public service.

\subsection{Functions Clarity between National and County Administrators in Respect with Devolved government System}

On the second objective which was to examine the extent to which functions of both County and National government administrators are interlinked, participants were required to indicate whether there are conflicts witnessed between the national and county government administrators at various managerial levels.

Table 2: Role Clarity between National and County Administrators

\begin{tabular}{lcc}
\hline Statements & Mean & $\begin{array}{c}\text { Std. } \\
\text { Deviation }\end{array}$ \\
\hline Most counties are yet to define their devolved functions & 3.82 & 0.86 \\
$\begin{array}{l}\text { No visible demarcation of the functions upon which the national and county governments } \\
\text { should unanimously deliver on their roles. }\end{array}$ & 4.05 & 0.77 \\
There is no set model of determining disasters responses by the either level of government & 3.87 & 0.72 \\
Resource allocation has been Inequitable in the national and county governments & 4.13 & 0.78 \\
There is confusion in health care functions especially ambulances and maternity & 4.08 & 0.66 \\
management & 3.68 & 0.72 \\
Maintenance of secondary roads presents a concern due to role overlap between the ministry & \\
Transport and the county public works & 3.82 & 0.77 \\
Unbundling especially in procurement process and subsequent costing was not effectively & 4.12 & 0.59 \\
To fight crime at the grassroots, top county security chiefs to work in harmony with the & & \multirow{2}{*}{ governor for the common good of the citizens } \\
There should be links between these offices to facilitate exchange of intelligence and vital & 4.21 & 0.58 \\
information & 3.84 & 0.62 \\
There are tensions between governors and the county commissioners & 3.78 & 0.70 \\
The functions of the county security team should be clearly described &
\end{tabular}

From the research findings majority of the respondent's agreed that there should be links between these offices to facilitate exchange of intelligence and vital information $(\mathrm{M}=4.21 \mathrm{SD}=0.58)$. The study however, found out that resources were being unequally allocated between the two levels of government $(\mathrm{M}=4.13 \mathrm{SD}=0.78)$. The study established that to fight crime at the grassroots, top county security chiefs to work in harmony with the governor for the common good of the citizens $(\mathrm{M}=4.12 \mathrm{SD}=0.59)$. There is confusion in health care functions especially ambulances and maternity management $(\mathrm{M}=4.08 \mathrm{SD}=0.66)$ These findings agree with the study findings by Ayee, (2017), Restructuring the various government units to reflect provision of the constitution in particular this envisaged restructuring of the provincial administration has been a tall order.

Interviewees reported the county governments are trying to improve most of the previously left out health facilities into institutions that are able to handle most health challenges. The study established that most counties were yet to define their devolved functions $(\mathrm{M}=4.05 \mathrm{SD}=0.77)$ and that there are no set model of determining disasters responses by the either level of government $(\mathrm{M}=3.87 \mathrm{SD}=0.72)$. There are tensions between governors and the county commissioners $(\mathrm{M}=$ 
3.84 SD =0.62). Provincial Administration under a new constitutional order is critical in providing a management system for intergovernmental connection on matters of policy crosscutting through several counties. There is no visible demarcation of the functions upon which the national and county governments should unanimously deliver on their roles. $(\mathrm{M}=3.82 \mathrm{SD}=0.86)$. These findings accede to the study findings by White and Smoke (2005), who notes by the Constitution allowing national and counties to initiate devolved projects has brought about the ambiguity in the allocating of functions between the two levels. The Inter-Governmental Relation Act 2012 calls for initiation of intergovernmental sector forums on shared function by the national and county governments. However, lack of administrative procedures, enforcement mechanism and the fact that the decisions of the forums are not binding have held this provision at bay. The Act's provision for the Intergovernmental Relations Technical Committee is yet to be operationalized thereby defeating its effectiveness in discharging its mandate. Further the findings revealed that the functions of the county security team should be clearly described ( $m=3.78 \mathrm{SD}=0.70)$ and Maintenance of secondary roads presents a concern due to role overlap between the ministry Transport and the county public works $(\mathrm{M}=3.68 \mathrm{SD}=0.72)$. These findings concurs with Padilla (2012), to function efficiently, administrations must be attributed by a well-defined chain of command, specialization, job description,, work ethics,, team relations, and employee selection, and promotion on merit.

The two levels of government are distinct and interdependent and should relate through consultation and cooperation. (Kenya Constitution 2010, Articles 6(2) and 189). Therefore the two levels are expected to exercise their functions without jeopardising each other. The Intergovernmental Relations Act, 2012 has spelt out the legal and institutional framework upon which the two levels of government shall consult, cooperate and resolve disputes. The Act has provided for three bodies upon which its mandate will be fulfilled: These bodies include; the National and County Government Coordinating Summit, the Intergovernmental Relations Technical Committee and the Council of County Governors.

\subsection{Challenges faced in the implementation of Schedule Four of the constitution}

The study sought to establish whether there were any challenges encountered in the implementation of Schedule Four of the constitution. Majority of the respondent's (72.8\%) agreed that there are challenges faced in the operationalization of schedule four of the constitution whereas $27.2 \%$ of the respondents were of the contrary opinion. This implies that are challenges faced in the operationalization of Schedule four of the constitution. The study sought to determine the extent to which these challenges affected the operationalization of Schedule Four of the constitution.

Table 3: Challenges faced in the Operationalization of Schedule Four of the constitution

Std.

All powers provided in schedule four of the constitution should be transferred at once

Mean Deviation

Many county governments, lack the capacity to absorb all such powers within such a short term

$3.86 \quad 0.77$

County governments have less financial resources and authority to ensure equal distribution of power

$4.01 \quad 0.80$

County governments are gaining in authority, powers and legitimacy and become more prominent in driving local economic development

$3.85 \quad 0.77$

Administrative and bureaucratic culture complicates the devolution process

$3.90 \quad 0.72$

$4.12 \quad 0.68$ 
International Journal of Current Aspects, Volume 4, Issue 2, 2020, PP 50-68, ISSN 2616-6976

[IJCAB

Std.

\begin{tabular}{|c|c|c|}
\hline & Mean & Deviation \\
\hline $\begin{array}{l}\text { Budgetary bottlenecks have crippled many of the counties thereby affecting many of the plans } \\
\text { they had to increase investments on security. }\end{array}$ & 3.82 & 0.79 \\
\hline $\begin{array}{l}\text { The presidency and administrative bureaucracy use welfare and security of the people as an } \\
\text { excuse to revoke the rule of law and administrative justice }\end{array}$ & 3.75 & 0.81 \\
\hline $\begin{array}{l}\text { lack of audit reports for infrastructures, assets and liabilities inherited from former local } \\
\text { councils }\end{array}$ & 3.84 & 0.73 \\
\hline $\begin{array}{l}\text { understanding of main concerns of devolution was a source of mistrust between stakeholders } \\
\text { with some, especially the minority political party coalition, foreseeing that the national } \\
\text { government is working to short change devolution }\end{array}$ & 4.09 & 0.67 \\
\hline $\begin{array}{l}\text { Kenya currently lacks trained and experienced legislative drafters, fiscal and economic } \\
\text { planning experts for effective operationalization of schedule four of the constitution }\end{array}$ & 3.89 & 0.64 \\
\hline $\begin{array}{l}\text { Failure to appoint members to key institutions and commissions remains a key concern for } \\
\text { effective operationalization of schedule four of the constitution. }\end{array}$ & 3.90 & 0.70 \\
\hline $\begin{array}{l}\text { The } 15 \% \text { of national revenue allocation to counties is not sufficient to enable counties to } \\
\text { discharge all their duties effectively }\end{array}$ & 4.25 & 0.60 \\
\hline
\end{tabular}

From the research findings majority of the respondent's agreed that the $15 \%$ of national revenue allocation to counties is not sufficient to enable counties to carry out all their duties effectively (M $=4.25 \mathrm{SD}=0.60$ ), and that county governments are gaining in authority, powers and legitimacy and become more prominent in driving local economic development $(\mathrm{M}=3.90 \mathrm{SD}=0.72)$. The Spirit of devolution is Kenya is on cooperation and interlinkages, however, on some matters the National Government has an upper arm on county matters. It's in this regard that this study realised that the National Government financing to counties in its operations impedes the operation of county functions. The research found out that administrative and red tape culture harden the devolution process $(\mathrm{M}=4.12 \mathrm{SD}=0.68)$, which couple by the finding that Kenya currently lacks competed legislative drafters, fiscal and economic planning experts for effective implementation of schedule four of the constitution $(\mathrm{M}=3.89 \mathrm{SD}=0.64)$ stand out as major setbacks to the implementation of the schedule four of the constitution.

Strong Administrative cultures which involve organizational capacity for the long term ability of an organization to meet its mission by effectively achieving its objectives through a blend of sound management, strong governance and persistent dedication to attaining and assessing results through an institutional Strategic plan is wanting. The research found out that the counties lack the capability to contain such powers within short time $(\mathrm{M}=4.01 \mathrm{SD}=0.80)$, was a challenge to operationalize the scheduled four of the constitution. This was a felt challenge as the research brought in the light that it was the publics' wish to have all functions stipulated in schedule four be devolved at once $(\mathrm{M}=3.86 \mathrm{SD}=0.77)$. These findings agree with De Guzman and Reforma (2017) overlapping seems to be endemic in most departments adding that there are field personnel of the national government ministries operating parallel to those of counties.

These findings are in line with Mwenda (2010), who argues devolving resources and information to the point of service delivery is very key, though it has been overlooked by most of the counties. Mulwa \& Wekuyi (2010) hold a similar opinion and adds that information needed for decision making is at times lacking when needed. This is in line with O'Brien, et al (2003), who established that Counties lack a human resource policy leading to poor labour distribution and lack of competency development. According to them, Counties have less professional staff compared to sub-staff at the ratio of 1:4. This brings about the challenge of evaluation and capacity to strategize 
and implement the strategic goals. Mulwa \&Wekuyi (2010) concur with this and argue that the challenge of quality and properly distributed human resource make it hard to allocate and manage the service delivery process to the satisfaction of devolution expectations. The study revealed that the County lack a human Resource policy with structured working relationships. Human Resource Policy in the County to determine the human resource engagement and skills development is necessary for productivity and success in the work place. The study established that lack of understanding of main concerns of devolution was a source of mistrust between stakeholders with some, especially the minority political party coalition, foreseeing that the national government is working to short change devolution $(\mathrm{M}=4.09 \mathrm{SD}=0.67)$. This is in line with De Toni \& Tonchia (2003), who established that proper communication channels which involve the end-users strategically facilitate the coordination of County functions and improve quality and efficiency in service delivery; however, for most of the organizations this is not the case and County governments are not an exception. This study's respondents were in agreement that, Nairobi City County as any other organisation has its share of stakeholders whose interest will be imparted or impart the strategies and programmes of the City. These stake holders thereby are interested in ensuring that the policies will be in a position to shape the City towards there benefiting culminating to attaining of their objectives.

The constitution grants all citizens the right to access public information. Article 35 (3) provides for the government to publish and publicise all important information on the State. The County Government Act Section 93-96 calls for county government to initiate a mechanism and facilitate public communication and access to information in the form of media with the widest public outreach in the county. However, access to public information still persists to be a challenge and a source of mistrust. Other key stakeholders are members of the Nairobi City County Assembly and county employees though they constitute the county. The county employees are a major resource to the county in terms of skills, experience, accrued resource and relationship. Further the findings revealed that County governments have less financial resources and authority to ensure equal distribution of power $(\mathrm{M}=3.85 \mathrm{SD}=0.77)$, lack of audit reports for infrastructures, assets and liabilities inherited from former local councils by many county governments $(\mathrm{M}=3.84 \mathrm{SD}=$ 0.73 ), budgetary bottlenecks have crippled many of the counties thereby affecting many of the plans they had to increase investments on security $(\mathrm{M}=3.82 \mathrm{SD}=0.79)$ and that the presidency and administrative bureaucracy use welfare and security of the people as an excuse to revoke the rule of law and administrative justice $(\mathrm{M}=3.75 \mathrm{SD}=0.81)$. These findings concur with the research findings by Ponce (1994) endorse that national agencies hold a technical responsibility in facilitating the functioning of county governments. These similarly support the research findings by Reforma (1993) that duality of government service is viewed as the performance of the similar responsibilities by the two levels of governments' field offices simultaneously.

\section{Conclusion}

The retaining of the Provincial Administration in the Kenya Constitution and its former existence experience prove that government is a single enterprise unified and revolving through common purpose, behaviour, and reputation. Therefore, it must be restructured on this basis to ensure all government components and parts are unified along the Devolution structure with similar behaviour, reputation and purpose. It's in this understanding that the outlined structure in the National Government Coordination Act 2013 (table 4.7), intents to extent the National Government Arm to establish the administrative field units is the point of action as far as the National Government functions are concerned. Therefore, there is need to recognise a potential 
for cooperation of all functions at lower levels to the new structure in tandem with the Constitution through policy implementation in line with government procedures and general guidelines as laid down in this Act. It's important to note that the cascading of the National Functions to lower levels of service delivery will minimise red tape and dominance by the bureaucracy which was one of the many reasons for Kenyans' overwhelming voted for devolution. This study concludes structural complexities do arise from the fact that the national government is in a want to maintain the same authority that has been devolved to the lower level government thus subverting devolution. Under devolved structure, the chain of command is simple, less complex and non-confusing contrasted to the former provincial administration which had been accused of being the face of suppression, corruption and authoritarianism. Under devolved system, provincial administration advance national unity by acknowledging diversity and that it promotes participatory and transparent exercise of power.

On role clarity this study concludes that there is overlapping of functions between the national and county governments. Notwithstanding preceding, and identification of the fact that roles should be properly devolved through an institutionalised framework for effectiveness in implementation, there nevertheless exist occasions of duplication between the two levels of Governments. It is regrettable that there are cases, where some national government departments continue unperturbed to carry out constitutionally devolved county functions. Intergovernmental Relations Act, 2012 stipulates the framework where the two levels of government shall consult, cooperate and resolve disputes in the process of transferring or performing their functions. It's on this basis that the study conclude that some functions that are devolved to the county governments may still to some extent accountable to the national level of organization of government in the sense that the national government can set standards and norms for these functions based on consideration like economic unity.

\section{Recommendations}

This research recommends the need for concerted efforts in creation of awareness on matters devolution through a structured civic education program. This will enlighten members of public on their expectations, roles, operations of devolution and how to be involved in governance decision making. There is need for well-structured channels of government information dissemination and sharing to ensure all are in tandem with the current occurrences able to hold the government to account. A consideration for both internal and external environment when making operational decisions and availing needed information is key to attaining the envisaged devolution. There is a need to keep the devolution process clear of political interference, corruption and other vices as per the public Ethics Act. Curbing mismanagement will ensure that resources to achieve devolution goals through effective facilitation of equitable allocation for various purposes are well utilized and accounted for with transparency.

The County government should draw a Human Resource Development policy to handle all staff related matters. This should carter for; Skills and competency trainings for all government staff on good governance, culture change and other relevant technical skills, planning for human resource equipment and materials on need and priority based. The commission on Revenue allocation to focus on wards as the point of reverence in budgeting from Sub-County level as the wards are the points of service delivery. There is need to similarly put control measures in resource utilization to monitor and evaluate equitable allocation, policy and standard compliance and proper oversight roles. The government should strategically link the goals of all sectors to the strategic goal and 
provide for interlinkages for cooperation and synchronized working relationships towards vision 2030. Proper periodical reviews need be done to identify gaps and seal them.

It is necessary for the two levels of government within the intergovernmental arrangement to first agree on the overall structure of the service delivery mechanism and the general assignment of authority and responsibility over the key inputs that combine to form service provision regarding such sectors. That way, it is easy to discern how specific parts of service delivery should be operationalized and with whom lays such responsibility based on the sector under scrutiny. Given the high degree of concurrency in the division of powers, the close fiscal ties, and the extent of national supervision over county governments, cooperation among the two Level of government is level is critical. Cooperation and Intergovernmental relations may involve a wide array of institutional processes ranging from phone calls between civil servants to inter-ministerial meetings, from the creation of joint bodies to the creation of a variety of consultation mechanisms for purposes of deliberations on various aspects of government responsibilities and their delivery.

Reliance on the fourth schedule solely as the basis for determining the boundaries of responsibility as between the national and county governments in matters pertaining to the division of functions might back fire therefore there is need to, through cooperative government and intergovernmental relations, enact a national legislation on functions and powers to specify the constitutional assignment of functions and powers to the two levels of government, Fostering of effective intergovernmental relationships that will reduce institutional turfs wars and roles duplication. There is need to invest in capacity building initiatives that enhance the abilities of both levels of Government to deliver on their policy, legal and functional mandates provided for under the 2010 constitution. Deliberate strategies must be employed for purposes of identifying capacity gaps as well as designing activities that improve capacity performance especially on the part of the county governments.

\section{REFERENCES}

Allan Bryman. (2008) Social Research Methods ( $3^{\text {rd }}$ ed). New York: Oxford University Press inc. Armenakis, A., Harris, \& Feild, H. (2001) Paradigms in organizational change: Change agent and change target perspectives. In Handbook of Organizational Behavior, 631-658.

Barrow, J. (1977) The variables of leadership: A review and conceptual framework. The academy of Management Review, Vo. 2, No. 2, pp. 231-151

Bass, H. (1990) Study on the Impact of the Local Authority Service delivery Action plan. Nairobi: Kenya Local Government Reform Programme, Ministry of Local Government Vol. 48, No. 9, pp 223-227.

Behn, R. (1998) What right do public managers have to lead? Public Administration Review. Vol. 58, No. 3, pp 209-224.

Bittner, E. (1965). The concept of organization. An article based on a paper presented at the annual meetings of the American Sociological Association. Montreal: September

Blau, P. \& Schoenherr, R. (1970) The structure of organizations. (Vol. 24) New York \& London: Basic Books, Inc (2010)

Brewster, M \& Bournois, L, (2001). Decentralization of governance and development. Journal of Economic Perspectives. Vol. 16, \# 4, pp. 185-205

Brian, E. (2001). Trimming government into a more efficient form. Philippine Institute for Development Studies - Development Research News, Vol. XII, No. 4, pp. 8-12

Bruce, Katz. (2015). Where is the U.S. "devolution revolution" brookings.edu.cdn.amproject.org Burugu, N. J. (2010) The county: understanding devolution and governance in Kenya. 
Coffey, A. \& Atkinson, P. (1996) Making sense of qualitative data. London, \& New Delhi: Sage Publications Thousand Oaks

Constitution working paper series no.3, Nairobi: Society for International Development.

Cooper, D., \& Schindler D.S. (2003) Business Research Methods ( $8^{\text {th }}$ ed,) New York: Mac GrawHill

Creswell, K (2002) Research Methods: Quantitative and Qualitative Approaches. Nairobi: Africa Centre for Technology Studies, Acts Press

Davis, T. \& Luthans, F. (1979) Leadership reexamined: A behavioral approach. Academy of Management Review, Vol. 4, \# 2, pp. 237-248.

De Guzman, A., \& Padilla, L. (1992). The Emergence of Local Capacity: Lessons from Colombia. World Development, Vol. 25, No. 7, pp. 1029-1043

Goldsmith, G. (1995) Devolution in Kenya: Prospects, Challenges and Future Nairobi: Institute of Economic Affairs. IEA Research Paper Series No. 24, Pp. 8-13

Gonzales, J. (2002). Decentralization in an emerging multi-centered region: The direction of governance reforms in Asia, Inter-American Development Bank, Workshop on

Fesler. F. (1995) An Independent Study on the impact of the Local Authority Transfer Fund( LATF) in Kenya. Nairobi: Kenya Local Government Reform Programme, Ministry of Local Government, Government of Kenya

Fleishman, J. (1991). Trimming government into a more efficient form. Philippine Institute for Development Studies - Development Research News, Vol. XII, No. 4, pp. 8-12

Fleurke, F. \& Willemse, R. (2004). Approaches to decentralization and local autonomy: A critical appraisal. Administrative Theory and Praxis, Vol. 26, No. 4, pp 523-544.

Fleurke, E. \& Willemse, F. (2004) Perspectives on leadership: From the science of management to its spiritual heart. Westport, Connecticut / London: Praeger Publisher,

Harvey, E. (1968). Technology and the structure of organizations. American Sociological Review, vol. 33, \# 2, pp. 247-259.

Henry, O. (2016). Unfinished Business on Transition poses risk to Devolution Implementation. https//www.reject.awcfs.org

Joaquin, H. (2002). Guidelines for the Preparation, Implementation and Monitoring of Local Authority Service Delivery Action Plan (LASDAP). Nairobi: Government Printer

John, P. (2001) Local Governance in Western Europe. Thousand Oaks, CA, London, New Delhi: Sage Publications, Inc.

Johnson, C. (2005) Meeting the ethical challenges of leadership (2nd Edition) Thousand Oaks, California: Sage Publications, Inc.

Kauzya, P. (2007) Should local government buy in? The International Journal of Public Sector Management, vol. 7, No. 3, pp. 27-43.

Kelleher,J., Christine, S., Yackee, B, \& Webb (2004). An empirical assessment of devolution's policy impact. The Policy Studies Journal, Vol. 32, No. 2, pp. 253-270.

Kenya National Bureau of Statistics (2019). The National Population Census for 2019. Report published by the ministry of planning Nairobi. Government press.

Kirira, L, (2011). Decentralization and Devolution in Kenya: New Approaches.Nairobi: University of Nairobi Press.

Kombo \& Tromp. (2006) Research Methodology: Methods and Techniques. (2 ${ }^{\text {nd }}$ ed,). Daryaganj, New Delhi: New Age International (P) Ltd

Kothari, C.R. (2006) Research Methodology: Methods and Techniques. (2 ${ }^{\text {nd }} \mathrm{ed}$,). Daryaganj, New Delhi: New Age International (P) Ltd 
Kulipossa, F. (2004). Decentralization and democracy in developing countries: An overview. Development in Practice, 14(6), 768-778. Nairobi

Mouritzen, P. \& Svara, J. (2002) Leadership at the apex: Politicians and administrators in western local governments. Pittsburg, PA: University of Pittsburg Press.

Mugenda, O .\& Mugenda, A. (2003) Research Methods: Quantitative and Qualitative Approaches. Nairobi: Africa Centre for Technology Studies, Acts Press

Muli, J. (2014). The Challenges of implementation of devolution strategy at the Nairobi City County government in kenya. Thesis;en_US

Mwenda A. K. (2010) Devolution in Kenya. Prospects, Challenges, and Future. Nairobi: IEA Kenya

Nairobi County Government website www:nairobi.go.ke

Ndemo Salim (2007) Epitome of State Power: The Provincial Administration in Kenya. Nairobi:Regional Institute for Cooperative Development and Management

Nolledo, J. N. (1992). The local government code of 1991: Annotated. Manila, Philippines: National Book Store,

Northouse, P. (2004) Leadership theory and practice. Thousand Oaks, London, New Delhi: Sage Publications, Inc.

Obuya Bagaka (2011), Restructuring the Provincial Administration: An Insider's

Ocampo, G. (1992). Promoting Regulatory Reform at Local Government Level in Kenya. Paper presented at the Network for Regulatory Reformers Conference

Omolo A. (2010) Devolution in Kenya: A Critical Review of Past and Present Frameworks.

Opalo, R (2011). Does decentralization improve equity and efficiency in public service delivery provision. Brookings Institution Press. Pp. 75-91

Orieko, C. and Onesmus N. (2004) District Focus for Rural Development in Kenya:

Osborne, D. (1998) Political Decentralization in Africa:Experiences of Uganda, Rwanda and South Africa.

Padilla, F (1992). Understanding the Local Government System in Kenya: A Citizens Hand book. Nairobi: IEA-Kenya

Ponce, L. (1994). Trimming government into a more efficient form. Philippine Institute for Development Studies - Development Research News, Vol. XII, No. 4, pp. 8-12

Porter, D. O. and Olsen, E. A. (1976). Some critical issues in government centralization and decentralization. Public Administration Review, Vol. 36, No. 1, pp. 72-84.

Prachett, U., \& Wingfield, F. (1996). Further Dissecting the Black Box of Citizen Participation: When does Citizen Involvement Lead to good outcomes? Public Administration Review. Volume 71, Issue 6, pp. 880-892

Pranab, B. and Dilip, M. (2019). Decentralization and Local Governance in Developing Countries: A Comparative Perspective.

Reforma, S (1993.) Citizen Participation in Local Policy Making: Design and Democracy. International Journal of Public Administration, 35: 285-292

Rhodes, W. (1997). Decentralizing Governance: Emerging Concepts and practices. Washington: Brookings Institution Press.

Robert,Tannenwald (2012). Devolution in the United States: Theory and practice. https//Papers.ssm.com

Santiago, T., \& Joaquin G. (1998). Ministry of Local Government, Good Governance, Community Development and Social Affairs: Decentralization Policy 
Schneider. S (2003). Conceptual Explorations in Social Accountability. Public Management Review, 14:2, pp. 145-162

The Attorney General. (2010) Constitution of Kenya National Council of Law Reporting. Nairobi: Government Press

The Attorney General. (2012). The National Government Coordination Act National Council for Law Reporting. Nairobi: Government Press

The Transition to Devolved Government Act National Council for Law Reporting. The Attorney General. Nairobi: Government Press

Tony Bilton etl.(2002) Introduction to Sociology ( $4^{\text {th }}$ ed.) Hound mills: Palgrave MacMillan

Tapales, P, Cuaresma, J \& Cabo, W. (1998), Eds. Local Government in the Philippines: A Book of Readings. Vol. I, Local Government Administration, CLRG and NCPAG, University of the Philippines.

Tapales, P., Padilla, L. Joaquin, T., \& Santiago, E. (1996). Modern Management in Philippine Local Government, Local Government Center, University of the Philippines-College of Public Administration

Task force on Devolved Government (2011) A Report on the Implementation of Devolved Government in Kenya. Nairobi: Government Press

The Jamuhuri Magazine March Edition (2012): NairobiUSTAWI websitehttp://www.ustawi.infor/ke/index/php/govern

Wolman, H. (1990). Decentralization: What it is and why we should care, In R.J. Bennet (ed.) Decentralization, local governments, and markets: Towards a post-welfare agenda,

Oxford: Clarendon Press

White, F, \& Smoke B. (2005). Decentralizing Service Delivery Evidence and Policy Implications. Nairobi: IDS Bulletin

Winston, D (2002). The variables of leadership: A review and conceptual framework. The Academy of Management Review, Vo. 2, No. 2, pp. 231-151

World Bank Report (2005). The Provincial Administration versus the Devolved System of Governance in Kenya: Nairobi

Wright. S. \& Rudolph. L. (1994) does decentralization improve equity and efficiency in public service delivery provision? Nairobi :IDS Bulletin. Volume 38 Number 1. Pp. 7-17.

Ziblatt. G. and Dwyer. K. (2003). Participatory Instruments in Local Governance: Cases from Rwanda, South Africa, and Uganda. United Kingdom: Paper Presented at the Commonwealth Local 21Government Research Colloquium Cardiff

This is an open-access article published and distributed under the terms and conditions of the $(c) \mathrm{EY}_{\mathrm{Br}}$ Creative Commons Attribution 4.0 International License of United States unless otherwise stated. Access, citation and distribution of this article is allowed with full recognition of the authors and the source.

Authors seeking to publish with an International Peer Reviewed Journal should consider https://www.ijcab.org/ by writing to the Editor at editor@ijcab.org. The articles must be quality and meet originality test. 